\title{
What is modernization? Eurocentrism and periodization
}

\author{
Qué es la modernización? \\ Eurocentrismo y periodización
}

\section{Qu'est-ce que la modernisation? Eurocentrisme et périodisation}

\author{
James McNutt \\ Queen's University, Canada
}

\begin{abstract}
This discussion will attempt to elucidate the various employments of the term 'modernity' in historical scholarship. I argue, following Dipesh Chakrabarty's article "The Muddle of Modernity," that the use of the term modernity privileges those societies of the industrialized West. This focus on the modern privileges modernity as an era at the apex of societal development in those time periods where industrialization occurred. Through the course of this discussion, I also argue that this periodization encompasses an idealized modernity which was conceived as the pinnacle of human society. In this view, all other societies and time periods were in the process of mirroring the modernized society. The sources for this paper are various surveys of national history, ranging from the developed European nations, such as France and England, to the so-called 'developing' nations, such as South Africa and Pakistan. These monographs, despite their variety in content, share their focus of the state's attempt to develop and/or to maintain political institutions, as well as to acquire, to a varying degree, industrial capital. These focuses lend themselves to a somewhat 'Whiggish' perspective on history in which 'progress' ever increases through time toward the present day.
\end{abstract}

Key words: historiography, modernity, modernization, periodization, colonization.

RESUMEN

En esta exposición se intentará elucidar los diferentes usos del término 'modernidad' en el debate académico de la historia. Siguiendo el artículo de Dipesh Chakrabarty "The Muddle of Modernity," sostengo que el uso del término modernidad privilegia a las sociedades 
industrializadas occidentales. Esta atención sobre lo moderno privilegia a la modernidad como una era ubicada en el ápice del desarrollo social en los tiempo en los que se tuvo lugar la industrialización. A través del curso de la exposición, también señalo que esta periodización abarca una modernidad idealizada que fue concebida como la cumbre de la sociedad humana. Desde esta perspectiva, todas las otras sociedades y periodos de tiempo fueron creadas tomando como referencia la sociedad modernizada. Las fuentes para este trabajo son diversos estudios de la historia nacional, abarcando desde las naciones europeas desarrolladas, como es el caso de Francia e Inglaterra, hasta las denominadas naciones desarrolladas, es el caso de Sudáfrica y Pakistán. Estas monografías, a pesar de su variedad en cuanto a contenidos, comparten su interés en el intento estatal por desarrollar y/o mantener las instituciones políticas, así como adquirir, en diferentes grados, capital industrial. Estos enfoques se prestan de alguna forma al desarrollo de una perspectica "Whiggish" en historia en la que el 'progreso' siempre crece a lo largo del tiempo hasta el presente.

Descriptores: historiografía, modernidad, modernización, periodización, colonización.

\section{RÉSUMÉ}

Cette discussion tentera d'élucider les emplois variés du terme 'modernité' dans le savoir historique. Je soutiens, après l'article «Embrouillement de la modernité» ou (embrouillamini), que l'usage de ce terme 'modernité' privilégie ces sociétés de l'Ouest industrialisé. Cette mise au point sur le moderne privilégie la modernité comme une ère au sommet du développement de la société en ces périodes de temps où l'industrialisation a eu lieu. Au cours de cette discussion, je soutiens aussi que cette périodisation comprend une modernité idéalisée qui a été conçue comme l'apogée de la société humaine. Dans cette optique, toutes les autres sociétés et périodes étaient en processus de refléter la société modernisée. Les sources de cet article sont diverses enquêtes sur l'histoire nationale, s'étendant des nations Européennes développées, comme la France et l'Angleterre, jusqu'aux nations «en voie de développement» comme l'Afrique du Sud et le Pakistan. Ces monographies, malgré la variété de leur contenu, ont le même point central: l'État essaie de développer ou de maintenir ses institutions politiques ainsi que d'acquérir à divers degrés leur capital industriel. Ces points principaux se prêtent à une perspective plus ou moins «Whiggish» sur l'histoire selon laquelle le progrès croît sans cesse à travers les temps jusqu'à aujourd'hui.

Mots clés: historiographie, modernité, modernisation, périodisation, colonisation.

"Things fall apart; the centre cannot hold; Mere anarchy is loosed upon the world..." (William Butler Yeats, "The second coming")

$\mathrm{I}^{\mathrm{N}}$ N THE 1936 FILM, Modern Times, Charlie Chaplin struggles to adapt to working life in an increasingly mechanized society. Through a series of mishaps befitting the slapstick genre, Chaplin finds himself on a conveyor belt, about to be devoured by a machine. This vignette, along with subsequent scenes where we see Chaplin being 'processed' through the inner workings of the machine, has been referenced by various scholars to symbolize the antagonisms of man and machine (Kotkin, 2001, p. 112; O'Shea, 2013, p. 7; Tolish, 1992, p. 344). Although Chaplin's film and Yeats' poetics mark the modern period as a humanistically subversive and melancholic era, these artists locate the character of modernity in materialism ("[ $t]$ hings fall apart"). While such sentiments may present a rather pessimistic view of modernity, these 
themes suggest the salient nature of industrialism in the modern period. Indeed, historians have often characterized modernity as an era of progress as well as warfare and destruction (Davenport \& Saunders, 2000, pp. 194-232; Kedward, 2006, pp. 62-87; Merriman, 2004, pp. 553-597, 1157-1206). This discussion will attempt to elucidate the various employments of the term 'modernity' in historical scholarship. I will argue, following Dipesh Chakrabarty's article “The Muddle of Modernity," that the use of the term modernity privileges those societies of the industrialized West. This focus on the modern also privileges modernity as an era the apex of societal development in those time periods where industrialization occurred. In this view, all other societies and time periods were in the process of mirroring the modernized society. These cultures were consigned to what Chakrabarty (2011) has called "the waiting room of history" (p. 664). If we are to heed David Armitage's call for the histories of the future to be both global and trans-historical, the biases surrounding the word 'modern' must be identified in order to advocate for the avoidance of such biases (Armitage, 2014). To this end, this paper will endeavour to delineate some of the characteristics of modernity by examining the manner in which national histories are depicted. All efforts have been made to ensure an equal representation of national histories among European and non-European states. This equal concentration will allow for comparisons to be drawn and will demonstrate how a particular variety of nineteenth and twentieth century European society was employed as an overlay to which developing societies were to conform, and to which it was anticipatory that pre-modern societies would become.

The sources for this paper are various surveys of national history, ranging from the developed European nations, such as France and England, to the so-called 'developing' nations, such as South Africa and Pakistan. These monographs, despite their variety in content, share their focus of the state's attempt to develop and/or to maintain political institutions, as well as to acquire, to a varying degree, industrial capital. These focuses lend themselves to a somewhat 'Whiggish' perspective on history in which 'progress' ever increases through time toward the present day. Undoubtedly, a component of this tendency stems from the desire to trace from its origins the lineage of one's current political and societal conditions. However, John Tosh (2006) elaborates on the fallacy of these interpretations, commenting "'Whig' history exhibits a tendency to underestimate the differences between past and present - to project modern ways of thought backwards in time and to discount those aspects of past experience which are alien to modern ideas. In this way it reduces history's social value, which derives largely from its being a storehouse of past experiences contrasted to our own" (p. 190). This accusation is not to deny the presence of events not generally deemed progressive, such as war and conflict, within the pages of these texts. The twentieth century, after all, was the site of two horrific world wars. Notwithstanding this fact, I contend that it is, in any given time period, the connection with our own present era, in terms of societal structure, that allows historians to allocate the 'modern' designation. Thus, the modern period is, in fact, presentist in nature. For example, as I further expound herein, it is only when political and legal systems become more or less recognizable to our present methods of governance and jurisprudence that the 
modern period is said to have begun. Granted, any written history encompasses an element of the author's present era. However, the anticipatory nature of the modern period often presupposes the telos of today; referring to the 'modern' or to 'modernization' characterizes the time period as an immediate stepping stone to the present. Although the tendency toward 'Whiggish' presentism may be unavoidable, we must be aware of this inclination and struggle against such propensities. My purpose for engaging in this discussion is to raise awareness among educators of history as to the propositions invoked by designating a certain period as 'modern.'

A delineation of the terms 'modernization' and 'modernism' which I have employed throughout this paper may be described as follows. Modernization may be thought of as the acquiring and maintenance of newly-fashioned infrastructure, along with the capital which emanated from that infrastructure. Comparatively, in the words of Chakrabarty (2011) following the scholarship of Marshall Berman, modernism suggests that 'the modern' refers to "our aesthetic response to modernization” (p. 664). Thus, modernization connotes a materialistic judgment concerning the amount of industrial implements, machinery, material, or networks a nation may control, as in the statement 'Britain modernized faster than Russia because of the development of the factory system.' Alternatively, modernism represents a more subjective designation which involves a cultural evaluation. This conception of modernization and modernism foregrounds Eurocentric normativity as the vision toward societal advancement. Evidently, this Eurocentric notion of modernity has been employed as a framework to narrate the past of the developing world.

Critics of modernity have long noted the presence of Eurocentrism circulating within Western discourses. ${ }^{1}$ As Chakrabarty (2011) comments, "[t]he Eurocentrism of European ideas of "modernity" and its connection to colonial domination is now acknowledged almost universally” (p. 664, n. 6). Indeed, the pre-eminence of Europe, both culturally and metacognitively, signifying the manner in which European ideas pervade the Western psyche and field of reference, is unequalled. In order to investigate how Eurocentric notions manifest in historical scholarship, it may be useful to explore the origins of these ideas of dominance. The notion of Eurocentrism may, perhaps, be traced to the Greek and Roman conception of civilization. This possibility is suggested by Anthony Pagden (1999) who comments that, "[f]or the Greeks and their Roman heirs the means of establishing a relationship between them and the rest of humanity rested upon a complex theory of climate and physical environment. This claimed that the northern parts of the world were inhabited by peoples whose inhospitable climates had made them brave and warlike, but also uncouth, unthinking, and - to use the Latinized term which will become central to all modes of European self-fashioning - 'uncivilized" (p. 5). These "uncivilized" 'barbarous northern types' were compared to "the Asians," who were characterized as "quickwitted, intelligent; but also, lethargic, slow to act, and ultimately corrupt" (p. 5). In this taxonomy of civilization, these soon-to-be Europeans, who were identified at this point as Mediterranean, represented a solitary bastion of propriety and moral correctness. This sense of superiority remained active when, in the eighteenth century, Montesquieu compared political systems. The notable philosophe rationalized 
that " $[\mathrm{m}]$ ost of Europe... is ruled by 'custom'... [while] Asia, and still darker regions of Africa and America, is ruled by despots," a situation which favoured the European system of government, according to Montesquieu (Pagden, 1999, p. 6). These examples demonstrate that Europeans have had a long-running history of considering their form of civilization superior. For his part, Chakrabarty has explored this Eurocentrism within his scholarship.

The theoretical basis of this discussion is indebted to Chakrabarty's postcolonial view of periodization. In his article "The Muddle of Modernity," Chakrabarty advances his concerns over the applicability of the modernity periodization to denote time periods marking the history of South Asia. Indeed, Chakrabarty frames periodization as a matter of controversy in the South Asian context. Chakrabarty (2011) claims that, in contrast with the more traditional South Asian historians who view modernity as synonymous with the start of British rule, some South Asian historians desired "to give the so-called modern period a longer and 'indigenous' past extending into the centuries before British rule" (p. 667). This extension would allow South Asians to view their forefathers as more than the protesters or 'the oppressed' within the realm of modern history, linking this past with contemporary society. This desire for a less-than-Eurocentric sense of the past is directly connected to Chakrabarty's postcolonial sentiments that he displayed as a part of the Subaltern Studies Collective. The Subaltern Studies Collective was an academic forum consisting of mostly South Asian scholars who grappled with the issue of documenting the histories of those traditionally not in the purview of historical scholarship in order to gain a more holistic view of the past on the subcontinent. Crucial to this endeavour is the diversification of historical scholarship questioning the hegemony which pervades Western historical thought and periodization.

To this end, Provincializing Europe: Postcolonial Thought and Historical Difference, a work which Chakrabarty wrote under the auspices of the Subaltern Studies publishing series, seeks to imagine a world that delegitimizes Europe as a locus of power and referent. However, Chakrabarty admits that this act of imagination requires the conception of the impossible, for European intellectual heritage is pervasive in our notions of the contemporary world. As Chakrabarty (2000) notes, "concepts such as citizenship, the state, civil society, public sphere, human rights, equality before the law, the individual, distinctions between public and private, the idea of the subject, democracy, popular sovereignty, social justice, scientific rationality, and so on all bear the burden of European thought and history. One simply cannot think of political modernity without these and other related concepts that found a climactic form in the course of the European Enlightenment and the nineteenth century" (p. 4). Crucially, Chakrabarty frames this list of European conceptions as integral to the global lens of "political modernity," transcending the continental landscape from which these conceptions emanated. However, this assertion leads to the question of whether or not modernity is Eurocentric in nature. Indeed, modernity may be thought of as a historicized concept in which Europe's quality of modernity is exported around the globe. This 'first in the West, and then elsewhere' notion seeks to confirm the European monopoly on the production and exportation of the modern 
(p. 6). However, this sense of modernity encompasses a multitude of conceptions.

In his discourse, Chakrabarty (2011) discerns a particular conception of modernity, arguing " $[\mathrm{m}]$ odernity in the West... alludes to two separate projects that are symbiotically connected. One refers to processes of building the institutions (from parliamentary and legal institution to roads, capitalist businesses, and factories) that are invoked when we speak of modernization. The other refers to the development of a degree of reflective, judgmental thinking about these processes" (p. 669). Through this distinction, Chakrabarty demonstrates that modernity implies both the establishment of modernization and the ability to identify and render a discourse concerning modernization. Chakrabarty confirms that " $[\mathrm{t}]$ he latter is what is often invoked by the term 'modernity.' The distinction is, of course, only analytical, for the development of ideas and the development of institutions are in reality intertwined processes" (p. 669). This discussion, therefore, through the exploration of ways in which modernity is employed in historical discourse, invokes the infrastructure and referent of modernity. The word modern, when employed in historical scholarship, conjures images of progress and advancement.

Perhaps the key to understanding the modern period is to ask: When did this era begin? Not surprisingly, there is little consensus among historians concerning the matter. John Merriman, while writing a general narrative of Europe, locates the seeds of modernity within the French and Industrial Revolutions. Ironically, Rod Kedward, with the comparatively focused task of detailing France's past, dates modernity to the turn of the twentieth century. In favour of Merriman's case, in A History of Modern Europe: From the French Revolution to the Present, the French Revolution did alter the trajectory of political development in the West through the introduction of the tripartite slogan, liberty, equality, and fraternity. Indeed, Merriman (2004) characterizes the Revolution as the first earnest attempt to dismantle the structure of absolute monarchy, commenting " $[\mathrm{t}]$ he French Revolution of 1789 struck the first solid blow in continental Western Europe against monarchical absolutism on behalf of popular sovereignty (p. 467). Merriman interprets the French Revolution as in support of a particular type of democracy. Far from being the direct democracy of the Ancient Greek polis where, in theory, every man not enslaved was able to cast their vote on civic matters, the French Revolution is seen as important in asserting individuals' (albeit propertied males) rights to representative government.

Further, Merriman suggests that the French Revolution be read as a manifestation of the so-called Atlantic Revolutions which had first begun in the United States. Subsequent to the French Revolution, these revolutionary ideals spread to Latin America and Haiti. These revolutions shared similar notions of liberty and pursued the gaining of popular sovereignty (Merriman, 2004, p. 516). In short, Merriman locates modernity at a crucial juncture in the development of democracy, not only European but in a global sense. However, we may question the degree to which these revolutionary ideals truly reached across the Atlantic to include the average Haitian or the peasant farmers of Latin America. Indeed, the nature of these Atlantic Revolutions may have amounted to mere exportations of European ideas and their application to the local context. In any event, the French Revolution retains its 
position in Merriman's narrative as the inaugural event of the modern, due to its importance to the future development of a democratic society. Merriman emphasizes the impact of the French Revolution to the course of European history, commenting " $\mathrm{t}$ ] he creation of a republican government in France and the diffusion of republican ideals in other European countries influenced the evolution of European political life long after the Revolution ended. Issues of the rights of the people, the role of the state in society, the values of democratic society, notions of 'left' and 'right' in political life, the concept of the 'nation at arms,' the place of religion in modern society and politics, and the question of economic freedom and the sanctity of property came to dominate the political agenda" (p. 469). Dispelling any ambiguity, Merriman explicitly asserts that " $t$ ] he political violence of [the] decade [1789-99] would also be a legacy for the future" (p. 469). Likewise, Merriman frames the Industrial Revolution as paving the way for a modern mechanistic society.

A second site of the commencement of the modern period, as identified by Merriman, was the first Industrial Revolution of 1800-1850 in Western Europe. Admittedly, Merriman (2004) places the roots of this technological expansion in the late eighteenth century, noting the importance of Adam Smith's economic treatises of the 1770s (p. 555). Although not blind to the social inequities caused by the great increase of industrial output, Merriman characterizes this period as being one of unparalleled growth. In Britain, for example, Merriman notes the expansion of the textile industry, indicating that the number of power looms for spinning fabric in the country soared from 2,400 in 1813 to 224,000 by mid-century (p. 571).

Furthermore, massive transformational changes were ushered in by the growth of the railroad companies and steamship industries and improved roads. By Merriman's account, "Britain had about 400 miles of rail in 1830, 6,600 in 1852; the number of railroad companies doubled between 1844 and $1850 \ldots$. [and] [b]y 1840 the transport of Irish cattle and dairy products to England alone fully engaged eighty steamships. A constant procession of steamships travelled the Rhine River from Basel, Switzerland, to the Dutch seaport of Rotterdam" (pp. 560-562). Taken together with the second Industrial Revolution occurring in the late nineteenth and early twentieth centuries, a culture of mechanization was contoured, which eventually produced the anxieties that Chaplin 'voiced' in his 1936 motion picture. This dream of progress, be it in peace or be it a nightmare, set the standard by which the character of global modernity is judged. There is arguably nothing to criticize regarding Merriman's assertion of the importance of such events as the French and Industrial Revolutions. Indeed, these revolutions were most certainly vital to the development of European society and global history. My argument lies with the fact that these types of events become the standard by which the modern in Europe is separated from modernity elsewhere.

Merriman's narrative imbues modern European history with a complex sophistication embodying the French and Industrial Revolutions as the commencement of the modern period. There is the sense that these revolutions began an entirely new era from the preceding early modern monarchal period. In contrast with this historically-minded division between the modern and pre-modern eras, Rod Kedward, in framing his monograph France and the French: A Modern History, seems to denote the 
modern as exclusive to the twentieth century. In questioning whether a longer timespan ought to be considered and whether the year 1900 represents an epistemological shift to the twentieth-century mindset, Kedward (2006) remarks, "I have taken 1900 [as a starting point for the modern] out of interest in the ways in which formalized beginnings, as well as ends, patterns self-awareness. Anniversaries, commemorations, festivals and set days of national holiday do the same. They act as ritualized conduits for expression and discovery: they are the rites of time" (p. 3). In short, Kedward chose the starting point of his monograph to be the turn of the century because contemporary individuals may have viewed the coming of the year 1900 as a momentous occasion, an opportunity for renewal. Despite this less-than-reasoned sense of historicization, one may discern some of the essential features of the twentieth century within Kedward's narrative, in delineating as to what the adjective 'modern' in his title refers.

Throughout the narrative of his text, Kedward describes the trajectory of events that the French people encountered, both inside and outside the republican nation. Two themes are immediately apparent when encountering this text: France's democratic republicanism, and France's maintenance of colonial power and control. As a vehicle for demonstrating the importance of republicanism, Kedward (2006) refers to the intellectual Julien Benda who held the conviction that "the French republic equated with reason, and France with universalism" (p. 9). Benda was an unapologetic idealist with a proclivity for Jacobinism. He believed that France embodied the essence of reason, truth, and good governance, proclaiming on the eve of World War I that "France, and France alone, incarnated the highest values of truth" (p. 9). In this paradigm, the twentieth century French nation is seen as a direct descendant of the Enlightenment ideals which emanated from the French Revolution, and other battles of ideology. Although Benda's particular zeal may have been uncommon in the modern period, the implementation of such high-minded values, such as truth and reason, were emblematic of the ideals voiced in the Revolution. Kedward seems to indicate that what differentiates the twentieth century from preceding periods following the French Revolution was that it became significantly difficult to maintain France's colonial projects while simultaneously endorsing Enlightenment rhetoric.

The development of a colonial ideology as a systematic form of domination became a clear component of the form of modernization in the twentieth century. A key feature of this domination was the use of education to inculcate the colonial ideology to the students who would become the future citizens of the colonizer's nation. To this end, Kedward places an emphasis on educating the colonial mindset when he argues that a notion of France was developed where the nation and its empire were united. This notion was emblematized in France's education system. As Kedward (2006) asserts, "France and its empire in the early twentieth century represented nearly 10 per cent of the world's land surface. French schoolchildren were quickly made familiar with this fact. They were rarely instructed that the colonies within the empire had cultures and histories of their own which pre-existed, and struggled to survive, the French imperial presence" (p. 11). The promoted unity was intended to encourage individuals to consider France a homogenized nation and to minimize 
diversity within its empire. Given this goal, education for citizenship was enacted to ensure the maintenance of the colonial empire. However, this domination exhibited a lack of compassion and regard for 'the Other' on the part of the state.

In contrast with Paulo Freire's notion of education for liberation, the implementation of France's colonial form of education serves to suppress individuality and diversity, promoting the domestication of students. The meaning of domestication in this context is two-fold and, admittedly, departs somewhat from the traditional Freirean connotation of the concept. First, this instruction promotes the development of students to become ideal colonialists who refrain from questioning the nation's foreign interests. Second, this type of education is accomplished through the implementation of Friere's 'banking concept of education,' whereby the students act as mere receptacles of information and the validity of the colonial doctrine and, by extension, the teachers' authority is unquestioned. According to Freire (1972), this education for domestication "divides teaching and learning, knowing and working, thinking and doing, informing and forming, re-knowing existing knowledge and creating new knowledge" (p. 177). Education for domestication and other forms of colonial discourse were characteristic of the modern period as detailed by Kedward.

Kedward (2006), following the educative conception of intellectual Ferdinand Buisson, cites that "the aim of education is to establish human dignity, to elevate the individual into a sacred and invulnerable being, whom no one in the world will be allowed to oppress or suppress" (p. 11). The ideals of Freire and Buisson, though separately formulated, sought to educate students in their becoming the future citizens of the modern period. As Kedward points out, however, the difference between who was included in this French citizenship and who was labelled a foreigner was determined by the French state. Taking the Algerian example, "French Citizenship had been decreed for Algerian Jews in 1870 by Adolph Crémieux, but nothing resembling civil or legal equality had been granted to the Arabs and Berbers in Algeria" (p. 15). This exclusion indicates that, if the freedom of the Enlightenment and colonialism were components of the modern period, those on the periphery of the European foreground would not acquire the enlightened benefits of the former. With regard to the latter, however, the colonial native knew all too well the painful symptom of modernity, as detailed in the monographs of the South African, South Asian, and Latin American histories discussed below.

If modernity on European continents is defined by technological and political complexities stemming from the 'advancements' of the Enlightenment and the Industrial Revolution, then colonialism outside European borders can be said to herald the arrival of the modern period. Indeed, a quick review of historical surveys may lead to the conclusion that to write modern history outside the European purview is to write the history of colonialism (Gillen \& Ghosh, 2007, pp. 199-216; Gouda, 1993, pp. 1-5; Slyomovics \& Stein, 2012, pp. 750-751). However, European predominance is inherent to colonial endeavours, leading to the pervasiveness and inescapability of the European worldview.

Illustrating the domination of colonial themes within historical scholarship, Rodney Davenport and Christopher Saunders, in South Africa: A Modern History, 
devote the bulk of the monograph to the history of the Cape nation after a recognizable colonial state had been established, evidence that Davenport and Saunders emphasize the colonial aspects in their narrative. Admittedly, this focus on colonialism may be the result of the authors' desire to chronicle a defining historical period, such as the nineteenth and twentieth centuries in South Africa. According to this view, colonialism was the major development in defining the political, economic, and cultural environment of the nation and, thus, deserves considerable attention. Colonial preoccupation, however, reinforces the European domination in the South African context.

In framing such a narrative, we locate power and authority largely within European hands, ignoring the mass of disenfranchised Black South Africans, or depicting them as subservient. For instance, in detailing the colonial period of 18201872, Davenport and Saunders (2000) include the narration,

"[a] tradition of journalism was born in the 1820s, as a result of the struggles of Thomas Pringle, John Fairburn, Abraham Faure and George Greig, to which beleaguered editors in the late twentieth century would often look back. The conflict between these men and Governor Lord Charles Somerset resulted after a four-year struggle in the official acceptance of three key principles: a presumption in favour of the right of individuals to obtain a licence to publish, subject only to the law of libel; their right to engage in political discussion; and their right to report events relating to the government of the Colony without pre-publication censorship." (p. 101)

While we may regard the history of South African journalism as vital to the development of the colonies and to South African freedom, this description represents a world alien to the experience of the majority of Black South Africa. Though South African history portrays reality and should not be forgotten, historians should be mindful of whose voices are heard and whose are not.

In accomplishing this task, Chakrabarty has suggested that we might reconsider the temporal boundaries of the modern to extend beyond the periods of colonial rule. This reframing of periodization would require a reconceptualization of what it means to participate in historical scholarship, as well as what constitutes historical evidence. Since the pioneering days of Leopold von Ranke, historical research has emphasized the truth of the verifiable written document. Shifting our modern periodization to preceding European conquest would necessitate the validation of alternative forms of evidence, such as oral history, as legitimate forms of knowledge. The reconceptualization of periodization would disrupt the Eurocentric view of progress where the development of governmental institutions and other establishments of modernity has constituted advancement over previous eras. By labelling these traditionally 'premodern' societies as exhibiting traits, whatever they may be, of the 'modern,' we place this society on the trajectory of contributing influentially to the character of our contemporary society.

Furthermore, through the consideration of what the Annales School has called 
the longue durée, we are able to gain historical perspective rather than subscribing to simply a narrative of progress. Still, this relabeling may lead to a teleological view that interprets as 'progress' the establishment of institutions which anticipate the current contemporary society status quo. In the context of this paper, I interpret teleology to be a history that anticipates the present, a continuous line toward a knowable current state of affairs. This type of historical narration may be unable to recognize events that do not congeal with this teleology. In order to combat this perception, we should revisit the long-discounted concept of 'value-free history.' Although I am not suggesting that this notion of history is attainable, the notion of progress and advancement within a teleological modernity may be considered ahistorical. Once again, perhaps striving for this ideal will allow us to reconsider how we value modernity.

Drawing on the insights of Chakrabarty on the issue of progress, framing the South African narrative in terms of progress rather than change reinforces a teleological perspective of modern history. An example of the teleological discourse occurs when Davenport and Saunders discuss the trajectory of 'South Africa' toward independence. As these historians comment, " $[\mathrm{t}]$ he progress of the Cape towards self-government took a course similar to that of British colonies of conquest and settlement elsewhere" (Davenport \& Saunders, 2000, p. 101). In this formulation, 'progress' implies that the current system of democracy and liberalism exhibited in South Africa is recognized as the ideal. The reframing of history would, perhaps, mitigate the implementation of this discourse.

On occasion, the teleological view of modernity may acquire racial connotations beyond those of representation. The impact of including a colonial discourse within a modernization narrative is that, if one does not proceed with caution, one may give the impression that the resulting advancement of the modernizing nation was due to the efforts of the colonizing nation. In short, this discourse would imply that the societal complexity of the contemporary nation represents proof of the success of the 'civilizing' mission propagated by the colonial powers. Ian Talbot, in Pakistan: A Modern History, provides an illustrative example of this failure. In one instance, Talbot (2009) details that the regions of Swat, Chitral, and Kalat, in what was then northwest India, were only indirectly ruled by Britain due to the mountainous terrain of the area and the security concerns arising from the "large areas of... volatile nomadic and semi-nomadic tribal communities" (p. 58). Subsequently, Talbot comments that, "[a]s a result of this system of indirect rule, they remained largely untouched by political, social and economic change elsewhere in India and were amongst the most backward areas of the subcontinent at the time of independence" (p. 59). Here, the word 'backward' is striking and, according to this statement, colonial rule was a necessary precondition for the future modernization of the country. I will assume that Talbot's use of the term 'backward' refers to the communities' lack of preparedness for entering into a democratic system; Talbot subsequently commented that the literacy rate in this region of Pakistan was under 2 per cent (p. 62).

This reading of South Asian history demonstrates little consideration for the tribal peoples' culture and attitudes toward Western-style democracy. Presuming that increased contact with the British would have 'cultured' these inhabitants, and, in 
turn, created a population more amenable to democratic institutions, does not consider the tribal peoples' autonomy. It is equally possible that these tribal communities failed to be fit for independence due to the Pakistan society's and, by extension, the political institutions' inability to integrate them as citizens. Rendering this alternative interpretation would allow South Asians agency, rather than attributing democratic modernization to colonial circumstance. As portrayed in Talbot's description, however, Britain's civilizing mission in South Asia is upheld. It should be noted that Talbot (2009) later addends that "[t]he post-colonial Pakistan state has maintained the main features of the British administration including the Frontier Crimes Regulations in the fifteen designated tribal areas in the Frontier, Balochistan and Dera Ghazi Khan district of Punjab... [and] [t] he remaining tribal areas were administered directly in the Frontier, Punjab and Sindh provinces of British India" (p. 59). Although it may be true, this statement emphasizes that British colonialism, and not the actions of the independence movement, paved the way for Pakistan's modernity.

Modernity in Pakistan may have been aided by British colonial rule prior to the advent of the South Asian nation's independence. However, colonialism in some other global contexts did not cease with the achievement of sovereignty. In Latin America, specifically in the period of 1870-1914, the specter of neocolonialism characterized the era of modernity. This neocolonialism comprised of European and American foreign investments that allowed Latin American governments and entrepreneurs to develop modernizing infrastructure across the region. Benjamin Keen and Keith Haynes provide one of the few texts which is broadly critical of a progressive discourse in A History of Latin America: Independence to the Present. Keen and Haynes (2004) interpret Western neocolonial investments as the continued domination of foreign powers in the region, despite such large investments as the US \$1.6 billion to promote Latin American interests in the period before the First World War (p. 220). In particular, upon the increased demand in foreign markets for Latin American products, such as Ecuadorian bananas, Keen and Haynes are critical of the expansion developments of haciendas throughout the area. Keen and Haynes remark, "[a]s the growing European demand for Latin American products and the growth of national markets raised the value of land, the great landowners in country after country launched assaults on the surviving indigenous community lands. In part at least, this drive reflected an effort to eliminate indigenous competition in the emerging market economy" (p. 218). Where a narrative of progress might have been written with ease, Keen and Haynes render a commendable and holistic perspective when admitting that economic growth may not have benefited some segments of the Latin American population.

Keen and Haynes reveal further disadvantages incurred by the indigenous people as a result of foreign investments. In order to encourage real estate development in Mexico, a law was enacted in 1894 which proclaimed that "a parcel of land to which a legal title could not be produced could be declared vacant land, opening the door to expropriation of land from indigenous villages and other small landholders whose forebears had tilled their lands from times immemorial but who could not produce the required titles" (Keen \& Haynes, 2004, p. 223). Taken together, such policies 
provided Latin America with capital through foreign investments and contributed to the modernization of the region. However, as the indigenous experience demonstrates, many inhabitants were left destitute, revealing the dark side of neocolonialism.

Along with narrating the plight of the indigenous population, Keen and Haynes also cite the experience of textile workers who worked up to 15 hours a day for very low wages, in factories financed and occasionally operated by foreign companies. In order to retain this foreign business, the Mexican government enacted a ban on labour unions and strikes. Despite this suppression, collective action in the form of wild cat strikes occurred, with devastating results. As Keen and Haynes (2004) note, " $[s]$ cores of workers, both men and women, were shot down by troops who broke the great textile strike in the Orizaba (Veracruz) area in 1909, and scores were killed or wounded in putting down the strike at the U.S.-owned Consolidated Copper Company mine at Cananea (Sonora) in 1906" (p. 225). Taken together, focusing on the plight of the indigenous inhabitants and the industrial workers, Keen and Haynes disrupt the narrative of "order and progress," a slogan which circulated throughout Latin America in this period (p. 220). To be sure, the policies affecting the marginalized indigenous minority and the industrial workers had positive impacts on the Mexican economy. For example, the Mexican land law allowed the expansion of foreign land holdings and, arguably, led to Mexico becoming "the largest producer of henequen, [agave fourcroydes] a source of fiber in great demand in the world market" (p. 224). Therefore, in contrast with Talbot's narrative, Keen and Haynes present a discussion critical of the ways in which Latin American neocolonialism contributed to the advancement of the region's inhabitants.

Notwithstanding Keen and Haynes's depiction of neocolonialism, there are indications that, at times, these authors accept a Whiggish narrative of ever-expanding progress toward a modern state. For instance, when discussing the history of Paraguay, Keen and Haynes (2004) recognize that the agrarian reform prior to 1840 was vital to the development of the country's economic and social position (p. 218). The introduction of new farming practices and redistribution of land certainly improved the populations' living conditions. Keen and Haynes remark, in their description of the agricultural innovations initiated in Paraguay, that " $[\mathrm{t}]$ heir state-directed program of agrarian reform and industrial diversification transformed Paraguay from a backward country into a relatively prosperous and advanced state" (p. 218). As mentioned in the discussion concerning Talbot's characterization of the remote tribes in Pakistan, the use of the word 'backward' implies that Paraguay, lacked in economic and/or political sophistication. This interpretation would be tantamount to rendering the value judgement of this 'pre-agrarian reform' in Paraguay as somehow pre-modern. Though Keen and Haynes present critical views of the 'economic success' fuelled by Western and European neocolonialism, they implicitly allocate disparaging judgement of the less-sophisticated or 'backward' states. As Chakrabarty (2011) states, "[i]f someone is 'modern,' then he or she is so with regard to somebody who is not. That 'somebody' may come to be seen as 'backward' or non-modern or waiting to be "modern" (pp. 663-664). This hierarchy is based on a modernization which positions Western and European democracies and economies at the pinnacle of civilization. 
Similar to the manner in which historians of the world employ the Western and European standards when judging the degree to which a nation has achieved modernity, historians of pre-modern history anticipate the arrival of the 'ideal' modernity.

While phenomena such as political and industrial revolutions or colonialism characterize modernism, that which comprises the 'early modern' appears to be of greater ambiguity. As Euan Cameron (1999) admits, “"[e]arly modern' is a description born of hindsight. It assumes that European culture was travelling towards something called 'modernity', but had not yet reached its goal: that the journey was begun, but not finished" (p. xvii). In contrast, South Asian historian John F. Richards (1997) comments, "[t]he term early modern is merely an attempt to capture the reality of rapid, massive change in the way humans organized themselves and interacted with other human beings and with the natural world" (p. 197). Despite Richards' statement, I agree with Cameron's assertion that to speak of the 'early modern' is to speak of an era which anticipates a modern industrialized society. Much of this teleology is evident in the form of contrasts. For instance, Cameron indicates that crop yields in the sixteenth and seventeenth centuries were modest, at best, compared with that in the more modern nineteenth and twentieth centuries. In a culture of abundance, the advancement of agricultural techniques and technologies have allowed for the increased cultivation of food which, in turn, has resulted in a healthier growing population, affording both luxuries and the time to enjoy 'the good life' (Cameron, 1999, pp. xxixxii). In this formulation, the disparity of the early modern period is recognized only when contrasted with the abundance of the modern. Although this depiction is accurate and fulfills the historian's mandate to document continuity and change across time, these facts provide evidence of the modern period advancements over earlier times. While identifying the agricultural development as an advancement seems logical, this discourse presumes an anthropocentric view. Such a view assumes that the sole purpose of existence on earth is for human development and prosperity. ${ }^{2}$ Seen in the light of climate change and the melting of the polar icecaps, we may question the degree to which our increased human development and prosperity constitutes a narrative of success. The population increase due to our societies' advancements may be seen as one more step toward the potentially catastrophic environmental issues of today.

Contemporary histories of the nineteenth and twentieth centuries share numerous commonalities. Among its various focuses, this history entails the European political and Industrial Revolutions and the specter of colonialism elsewhere. Furthermore, a Western and European culture of abundance is noted as prevalent, especially when compared with the early modern period. This paper argues that these characterizations are Eurocentric in nature and present European modernity as an ideal to which all cultures, past and present, may aspire. As we look toward the future, the prospect of global warming may fundamentally alter the manner in which our society and civilization functions and may lead to the necessity for redefining our conception of progress. In the final analysis, the mechanisms of modernity, as with Chaplin on the assembly line, are accelerating faster than our capacity to adapt. 


\section{Notes}

1. See Chakrabarty, D. (2000). Provincializing Europe: Postcolonial thought and historical difference. Princeton, NJ: Princeton University Press; Fabian, J. (1983). Time and the other: How anthropology makes its object. New York, NY: Columbia University Press; Pagden, A. (1999). Prologue: Europe and the world around. In E. Cameron (Ed.), Early modern Europe: An Oxford history (pp. 1-28). Toronto: Oxford University Press.

2. For more on anthropocentrism, see Soloman, D. (2013, January 21). "Dipesh Chakrabarty | Keynote | The Anthropocene Project. An Opening." HKW Anthropocene, Chicago, IL. https:/www.youtube.com/watch?v=svgqLPFpaOg.

\section{References}

Armitage, D. Horizons of history: Space, time and the future of the past. Lecture delivered at Queen's University, Kingston, ON, April 3, 2014.

Cameron, E. (1999). Introduction. In E. Cameron (Ed.), Early modern Europe: An Oxford history (pp. xvii-xxxi). Toronto, Canada: Oxford University Press.

Chakrabarty, D. (2011). The muddle of modernity. American Historical Review, 116(3), 663675. http://dx.doi.org/10.1086/ahr.116.3.663

Chakrabarty, D. (2000). Provincializing Europe: Postcolonial thought and historical difference. Princeton, NJ: Princeton University Press.

Davenport, R., \& Saunders, C. (2000). South Africa: A modern history. New York, NY: St. Martin's Press. http://dx.doi.org/10.1057/9780230287549

Freire, P. (1972). Education: Domestication or liberation? Prospects: Quarterly Review of Education, 2(2), 173-181.

Gillen, P., \& Ghosh, D. (2007). Colonialism \& modernity. Sydney, Australia: University of New South Wales Press.

Gouda, F. (1993). The gendered rhetoric of colonialism and anti-colonialism in twentiethcentury Indonesia. Indonesia (55), 1-5. http://dx.doi.org/10.2307/3351084

Kedward, R. France and the French: A modern history. (2006). New York, NY: The Overlook Press.

Keen, B., \& Haynes, K. (2004). A bistory of Latin America: Independence to the present (Vol. 2). Boston, MA: Houghton Mifflin.

Kotkin, S. (2001). Modern times: The Soviet Union and the interwar conjuncture. Kritika: Explorations in Russian and Eurasian history, 2(1), 111-164. http://dx.doi.org/10.1353/ kri.2008.0119

Merriman, J. (2004). A history of modern Europe: From the French Revolution to the present. New York, NY: W.W. Norton \& Company.

O’Shea, A. (2013). English subjects of modernity. In M. Nava \& A. O'Shea (Eds.), Modern times: Reflections on a century of English modernity (pp. 7-37). New York, NY: Routledge.

Pagden, A. (1999). Prologue: Europe and the world around. In E. Cameron (Ed.), Early 
modern Europe: An Oxford bistory (pp. 1-28). Toronto, Canada: Oxford University Press. Richards, J. F. (1997). "Early modern India and world history." Journal of World History, 8(2), 197-209. http://dx.doi.org/10.1353/jwh.2005.0071

Slyomovics, S., \& Stein, S. A. (2012). Jews and French colonialism in Algeria: An introduction. The Journal of North African Studies, 17(5), 749-755. http://dx.doi.org/10.1080/136 29387.2012.723427

Talbot, I. (2009). Pakistan: A modern bistory. New York, NY: Palgrave MacMillan.

Tolish, M. (1992). Bringing sociological concepts into focus in the classroom with Modern Times, Roger and Me, and Annie Hall. Teaching Sociology, 20(4), 344-347. http://dx.doi. org/10.2307/1318985

Tosh, J. (2006). The pursuit of history. Harlow, England: Pearson Education Ltd.

Yeats, W. B. (2006). The second coming. In by J. Stallworthy \& J. Ramazani (Eds.), The Norton anthology of English literature: The twentieth century and after (pp. 2036-2037). New York, NY: W.W. Norton \& Company. 